\title{
Pengaruh Model Pembelajaran Problem Posing Terhadap Prestasi Belajar Siswa MTs Al-Raisiyah Sekarbela
}

\author{
Dian Purwitarini \\ MTs Al-Raisiyah Sekarbela Mataram, Indonesia \\ dian@gmail.com
}

\section{ARTICLE INFO}

Article History:

Received : 20-03-2019

Revised : 11-05-2019

Accepted : 14-05-2019

Online : 22-05-2019

Keywords:

Problem Posing; Prestasi

Belajar

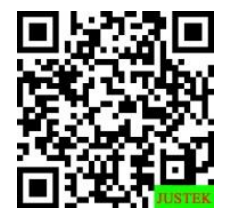

\section{ABSTRACT}

\begin{abstract}
This study aims to find out the influence of Problem Posing learning model on math learning achievement in class VII MTS AlRaisiyah comparison material. The type of research used was "quasiexpriment" involving 45 students consisting of two classes taken from three classes with purposive sampling techniques. The instruments used are study results test and observation sheet. Data analysis using $t$-test with 5\% signification level. The results showed that in the expriment class test obtained the highest score of 92 and the lowest 45 averaged 76.7 while in the control class obtained the highest score of 90 and the lowest 36 averaged 70.5. The calculation result obtained $t=-1,261>$ $1,714=t$-tabel resulted in Ha being accepted means there is an influence of problem posing learning models on learning outcomes.
\end{abstract}

\begin{abstract}
Abstrak: Penelitian ini bertujuan untuk mengetahui pengaruh model pembelajaran Problem Posing terhadap prestasi belajar matematika pada materi perbandingan kelas VII MTS Al- Raisiyah. Jenis penelitian yang digunakan adalah "quasi eksprimen" yang melibatkan 45 siswa yang terdiri dari dua kelas yang diambil dari tiga kelas dengan teknik purposive sampling. Instrumen yang digunakan adalah tes hasil belajar dan lembar observasi. Analisis data menggunakan uji t-tes dengan taraf signifikasi 5\%. Hasil penelitian menunjukkan bahwa pada tes kelas eksprimen diperoleh nilai tertinggi sebesar 92 dan terendah 45 rata-rata 76,7 sedangkan pada kelas kontrol diperoleh nilai tertinggi 90 dan terendah 36 rata-rata 70,5. Hasil perhitungan diperoleh $t=-1,261>$ $1,714=t_{\text {tabel }}$ berakibat $H_{a}$ diterima artinya ada pengaruh model pembelajaran problem posing terhadap hasil belajar.
\end{abstract}

\section{A. LATAR BELAKANG}

Pendidikan merupakan hak bagi setiap warganegara karena pendidikan dapat membawa dampak pada perkembangan ilmu pengetahuan dan teknologi yang bermanfaat dalam mengatasi permasalahan yang dihadapi oleh Negara (Permendikbud 2013)(Mahsup and Abdillah 2019). Dalam Undang-Undang Dasar 1945 pasal 31 disebutkan setiap warga negara berhak mendapat pendidikan dan pengajaran yang maknanya sesuai dengan pernyataan UNESCO tentang pendidikan untuk semua (Education for all) yang dideklarasikan di Jantion Thailand tahun 1990 dan diperkuat dengan deklarasi Salamanca tahun 1994 dan Dakkar pada tahun 2000 (Depdiknas 2003)(Mahsup and Anwar 2020). 
Pendidikan dan pembelajaran merupakan dua sisi yang tidak dapat dipisahkan, dimana pembelajaran selalu dikonotasikan dengan pelaksanaan pendidikan, dan pendidikan tidak dapat terlaksana tanpa adanya pembelajaran (Arta Diantoro, Mahsup, and Pramita 2019)(Mahsup 2018). Berhasilnya suatu proses pembelajaran sangat dipengaruhi oleh sistem pembelajaran (Kabunggul et al. 2020)(Mahsup et al. 2020). Salah satu komponen dari sistem pembelajaran itu sendiri adalah strategi atau metode (Aghni 2018)(Murtiah 2018). Dalam proses pembelajaran guru tidak harus terpaku dengan menggunakan satu metode, tetapi harus menggunakan metode yang bervariasi sehingga proses pembelajaran tidak membosankan, tetapi menarik perhatian siswa (Syaiful Bahri Djamarah 2006)(Puspita, Slameto, and ... 2018).

Berdasarkan hasil wawancara dengan guru matematika kelas VII di MTs Al-Raisiyah Sekabela, terdapat permasalahan yaitu rendahnya niilai rata-rata siswa pada ulangan harian perbandingan. Untuk VII ${ }^{\mathrm{A}}$ dengan jumlah siswa sebanyak 24 orang dengan nilai rata-rata 64 , kelas VII ${ }^{\mathrm{B}}$ dengan jumlah siswa 23 orang dengan nilai rata-rata 68 dan kelas VIIC dengan jumlah 26 orang dengan nilai rata-rata 64. Terlihat bahwa nilai rata-rata siswa masih dibawah KKM 75. Selain itu guru juga mengeluh tentang minat dan sikap siswa dalam mengikuti pembelajaran yang cenderung pasif dan lebih senang bermain dalam kelas, sehingga pemahaman tentang materi kurang dimengerti oleh siswa. Ini menyebabkan guru harus menjelaskan tentang materi yang sama secara berulang. Selain itu, penerapan metode oleh guru yang digunakan dalam pembelajaran matematika adalah metode ceramah, tanya jawab dan penugasan, serta kurangnya kesadaran siswa akan pembelajaran matematika. Pada proses pembelajaran hanya sekitar satu atau dua orang yang mampu menjawab pertanyaan guru, mengajukan pertanyaan guru dan mengeluarkan pendapat. Kebanyakan siswa terlihat bosan, tidak berminat dan malas dalam mengikuti proses pembelajaran matematika sehingga pada saat ulangan harian siswa tersebut tidak dapat mengerti maksud dari soal yang diberikan.

Pembelajaran problem posing adalah suatu kegiatan pembelajaran dimana siswa terlibat langsung dalam pembuatan soal dan menyelesaikan sesuai dengan konsep atau materi yang dipelajari (Sugita, Ashadi, and Masykuri 2016)(Hodiyanto and Haryadi 2018). Pembelajaran problem posing sebagai salah satu pembelajaran alternatif dapat meningkatkan minat dan sikap siswa terhadap pembelajaran matematika, karena penyajian materi dirancang menarik, variatif dan memacu siswa untuk aktif dalam proses pembelajaran (Syamsi 2012)(Akbar, Isnani, and Ponoharjo 2018).

Kelebihan problem posing yaitu (1) kegiatan pembelajaran tidak berpusat pada guru, tetapi dituntut keaktifan siswa; (2) minat siswa dalam pembelajaran matematika lebih besar dan siswa lebih mudah memahami soal karena dibuat sendiri; (3) semua siswa terpacu untuk terlibat memahami soal karena dibuat sendiri; (4) dengan membuat soal dapat menimbulkan dampak terhadap kemampuan siswa dalam menyelesaikan masalah; (5) dapat membantu siswa untuk melihat permasalahan yang ada dan yang baru diterima sehingga diharapkan mendapatkan pemahaman (Endah Tri Winihati et al. 2014)(Arum 2017). Tujuan peneliti ini yaitu untuk mengetahui pengaruh model pembelajaran problem posing terhadap prestasi belajar matematika pada materi perbandingan kelas VII MTs Al- Raisiyah sekarbela.

\section{B. METODE PENELITIAN}

Jenis penelitian ini adalah penelitian Quasi eksperimen dengan rancangan postest only. Sampel terdiri dari dua kelompok yang mana kelompok pertama yaitu kelas eksperimen diberi perlakuan berupa model problem posing dan kelompok kedua yaitu kelas kontrol tidak diberi perlakuan di ajarkan langsung oleh guru (Sugiyono 2016). Populasi dalam 
penelitian ini adalah kelas VII MTs Al- Raisiyah Sekarbela yang terdiri dari tiga kelas yaitu kelas VIIA, kelas VII ${ }^{\mathrm{B}}$ dan kelas VIIC. Teknik pengambilan sampel menggunakan purposive sampling, dengan menjelaskan bahwa purposive sampling dilakukan dengan cara mengambil subjek bukan didasarkan atas strata, random atau daerah tetapi didasarkan atas adanya tujuan (Arikunto 2010). Instrumen dalam penelitia ini adalah soal tes.

\section{HASIL DAN PEMBAHASAN}

Dari jumlah populasi 3 kelas, sampel diambil dua kelas dengan cara purposive sampling, yaitu satu kelas dijadikan kelas eksperimen (VII a) dengan jumlah siswa 23 orang dan kelas yang satu dijadikan kelas kontrol (VII b) dengan jumlah siswa 22 orang. Sebelum instrumen digunakan dalam pengumpulan data, data tersebut diuji coba untuk mengetahui tingkat validitas dan realibilitas instrumen yang bertujuan mengetahui tingkat kepercayaan instrumen agar memperoleh kesimpulan penelitian yang benar. Uji coba instumen ini dilakukan terhadap siswa kelas VIII c tahun pelajaran 2018/2019 sebanyak 26 responden diluar sampel penelitian. Jenis instrumen yang digunakan adalah tes uraian dengan jumlah item pertanyaan sebanyak 5 soal. Data mengenai hasil penelitian di MTs Al-Raisiyah Sekarbela tahun pelajara 2018/2019 pada kelas VII b (kelas kontrol) dan kelas VII a (kelas eksprimen).

a. Uji Validitas Instrumen Penelitian

Validitas bertujuan untuk menetahui kemampuan alat ukur terhadap konsep yang diuji. Perhitungan validitas instrumen penelitian dilakukan dengan menggunakan rumus korelasi product momen.

Tabel 1. Hasil Uji Validitas Instrumen

\begin{tabular}{llrrl}
\hline No & Item soal & $r_{x y}$ & $r_{\text {tabel }}$ & Keputusan \\
\hline 1 & Soal no 1 & 0,375 & 0,388 & Tidak valid \\
2 & Soal no 2 & 0,512 & 0,388 & Valid \\
3 & Soal no 3 & 0,482 & 0,388 & Valid \\
4 & Soal no 4 & 0,7085 & 0,388 & Valid \\
5 & Soal no 5 & 0,640 & 0,338 & Valid
\end{tabular}

Berdasarkan perhitungan diatas diperoleh $r_{\text {hitung }}=0,512$. harga $r_{\text {hitung }}$ tersebut kemudian dibandingkan dengan $r_{\text {tabel }}$, untuk $\mathrm{N}=26$ Maka $r_{\text {tabel }}=0,388$. sesuai dengan syarat bahwa suatu itam dikatakan valid jika $r_{\text {hitung }}>r_{\text {tabel }}(0,512>0.388)$ sehingga untuk item soal no. 2 dikatakan valid.

b. Uji Reliabilitas Instrumen Penelitian

Setelah dilakukan uji validitas kemudian dilanjutkan dengan uji reliabilitas yang dimaksudkan untuk mengetahui tingkat ketelitian instrumen apabila diujikan berulang kali yang diuji dengan rumus alpha karena intrument soal berupa soal uraian pada taraf signifikan $5 \%$ dengan $\mathrm{N}=26$ adalah 0,388. Rangkuman hasilnya tersaji dalam tabel berikut. Berdasarkan perhitungan diatas diperoleh rhitung $=0,060590$. Harga $r$ hitung tersebut kemudian dibandingkan dengan $r$ tabel, untuk $\mathrm{N}=26$ maka $\mathrm{r}$ tabel $=0,388$, sesuai dengan syarat bahwa suatu item dikatakan reliabel jika rhitung $>r$ tabel $(0,060590>0,388)$ sehingga untuk keseluruhan item soal dikatakan Reliabel. Setelah data dari setiap variabel terkumpul, kemudian dianalisis untuk menguji hipotesis penelitian dengan uji t. hasil uji t dapat diketahui setelah dilakukan uji normalitas dan homogenitas data sebagai syarat berlakunya uji $t$. setelah kelas eksprimen dan kelas kontrol dikenai perlakuan, kedua kelas tersebut diberikan posttest yang digunakan untuk mengetahui perbedaan prestasi belajar

a. Uji homogenitas 
Setelah data kedua kelompok sampel penelitian dinyatakan berdistribusi normal, selanjutnya mencari nilai homogenitas varians posttest dari kedua kelompok tersebut. Dari hasil pengujian homogenitas kelas eksprimen dan kelas kontol diperoleh nilai $F_{\text {hitung }}=1,020$ sedangkan $F_{\text {tabel }}=1,717$ pada taraf signifinkansi $\alpha=5 \%$. Berdasarkan hasil dari varians kedua kelas yaitu kelas eksprimen dan kelas kontrol memenuhi kriteria $F_{\text {hitung }} 1,020<F_{\text {tabel }} 1,717$ maka dari pengujian kedua kelas tersebut dapat disimpulkan bahwa kedua sampel yang uji adalah homogen.

b. Uji Normalitas

Dengan menggunakan uji Chi kuadrat untuk kedua kelas diperoleh kelas kontrol dengan harga Chi kuadrat $=40,167$ dan kelas eksprimen Chi kuadrat $=53,745$. Harga tersebut kemudian dibandingkan dengan harga chi kuadrat table dengan $\mathrm{dk}=\mathrm{k}-1=6$ $1=5$, bila dk 5 dan taraf kesalahan $5 \%$, maka harga Chi kuadrat $=11,070$. Karena harga Chi kuadrat hitung lebih dari harga Chi kuadrat table $(40,167<11,070), 53,745<11,070$ maka data posttest kelas kontrol dan eksprimen berdistribusi normal. Dari hasil penelitian yang telah dilakukan uji homogenitas data bahwa $F_{\text {hitung }}<F_{\text {tabel }}$, dari hasil tersebut kemudian dilanjutkan dengan pengujian hipotesis. Uji $t$ data posttest menjawab soal perbandingan kelas eksprimen dan kelas kontrol ini, bertujuan untuk mengetahui perbedaan rata-rata nilai akhir dari kelas tersebut. Adapun hasil evaluasi belajar kelas kontrol dengan nilai tertinggi 90 dan nilai terendah 36 dengan rata-rata 70,5. Pada kelas eksperimen dengan nilai tertinggi 92 dan nilai terendah 45 dengan rata-rata 76,7. Dari

hasil penelitian yang telah dilakukan uji homogenitas data bahwa $F_{\text {hitung }}<F_{\text {tabel, }}$ dari hasil tersebut kemudian dilanjutkan dengan pengujian hipotesis. Nilai $t$ hitung sebesar $1,261>1,714 t$ tabel. Ini berakibat $H_{0}$ ditolak dan $H_{a}$ diterima. Jadi model pembelajaran problem posing pengaruh terhadap prestasi siswa pada materi perbandingan Kelas VII MTs Al- Raisiyah Sekarbela.

\section{SIMPULAN DAN SARAN}

Berdasarkan analisis data hasil penelitian -1,261 >1,714 dapat disimpulkan bahwa ada pengaruh model pembelajaran problem posing terhadap hasil belajar matematika materi perbandingan pada siswa kelas VII MTs Al-Raisiyah Sekarbela semester genap. Saran dalam penelitian ini adalah sebaiknya guru berperan sebagai fasilitator dan motivator dalam proses pembelajaran dan memerankan siswa sebagai pusat dari proses pembelajaran dan diharapkan semua peserta didik aktif dalam proses pembelajaran, baik secara fisik maupun mental, sehingga apa yang dipelajari bisa bermanfaat dan bermakna bagi dirinya.

\section{UCAPAN TERIMA KASIH}

Ucapan terima kasih diberikan kepada kepala sekolah yang sudah memberikan dukungan dan semangat selama penelitian sehingga penelitian ini dapat dilaksanakan dengan baik.

\section{REFERENSI}

Aghni, rizqi alyasa. 2018. "Menurut Wina Sanjaya." fungsi dan jenis media pembelajaran dalam pembelajaran akutansi.

Akbar, Romi, Isnani Isnani, and Ponoharjo Ponoharjo. 2018. "Keefektifan Model Pembelajaran Problem Posing Tipe Post Solution Posing Terhadap Minat Dan Prestasi Belajar Matematika." Integral (Jurnal Penelitian Pendidikan Matematika) 1(1): 28-33.

Arikunto. 2010. “Suharsimi Arikunto.Pdf.” In Prosedur Penelitian Suatu Pendekatan Praktik- 
Revisi Ke X,.

Arta Diantoro, Syaiful Barsa, Mahsup Mahsup, and Dewi Pramita. 2019. "Penerapan Model Pembelajaran Kooperatif Tipe Two Stay Two Stray (TSTS) Dalam Meningkatkan Hasil Belajar Bentuk Aljabar Siswa Kelas VII SMP.” Paedagoria|FKIP UMMat 10(1): 01.

Arum, Wahyuni Fajar. 2017. "Pengaruh Model Pembelajaran Double Loop Problem Solving Dan Problem Posing Pada Materi Fluida.” Jurnal Teknika STTKD 4(2): 40-50.

Depdiknas. 2003. "Undang-Undang Republik Indonesia Nomor 20 Tahun 2003 Tentang SISDIKNAS Dan Peraturan Pemerintah RI Tahun 2015 Tentang Standar Nasional Pendidikan Dan Wajib Belajar." Citra Umbara: 1-33.

Endah Tri Winihati, Irene, Budi Usodo, Program Magister Pendidikan Matematika, and PPs Universitas Sebelas Maret Surakarta. 2014. "Pengaruh Model Problem Posing Setting Kooperatif Terhadap Prestasi Dan Minat Belajar Matematika Siswa Kelas X SMA Di Kabupaten Merauke Ditinjau Dari Gaya Kognitif Siswa." Jurnal Elektronik Pembelajaran Matematika 2(4): 2339-1685.

Hodiyanto, Hodiyanto, and Rahman Haryadi. 2018. "Pengaruh Model Pembelajaran Problem Posing Dengan Pendekatan Realistik Terhadap Kemampuan Komunikasi Matematis Mahasiswa." JINoP (Jurnal Inovasi Pembelajaran) 4(2): 132.

Kabunggul, Yosua et al. 2020. "Meningkatkan Motivasi Dan Hasil Belajar Siswa Melalui Penerapan Model Pembelajaran Team Game Tournament Berbantuan Media ...." Jurnal Pendidikan Karakter 3(2): 3-6.

Mahsup, and Abdillah Abdillah. 2019. "Penerapan Pembelajaran Metode Diskusi Untuk Meningkatkan Hasil Belajar Matematika Mahasiswa Pada Materi Determinan.” Jurnal Ulul Albab 23(1): 33.

Mahsup, and Y. S. Anwar. 2020. "Development of Structured Modules to Improve the Mathematical Understanding of the Circle Concept in Class VIII Mataram 17 Junior High School." In Journal of Physics: Conference Series, .

Mahsup, Mahsup. 2018. "Analisis Kesulitan Dalam Memahami Kemampuan Verbal Dalam Membuat Model Matematika Program Linear.” Jurnal Ulul Albab.

—. 2020. "Peningkatan Hasil Belajar Mahasiswa Melalui Model Pembelajaran Tutor Sebaya." Jurnal Kependidikan: Jurnal Hasil Penelitian dan Kajian Kepustakaan di Bidang Pendidikan, Pengajaran dan Pembelajaran.

Murtiah, B. 2018. "Penerapan Pendekatan Kontekstual Menggunakan Media Gambar Binatang Untuk Meningkatkan Keterampilan Mendeskripsi Secara ....” JUSTEK| Jurnal Sains \& Teknologi.

Permendikbud. 2013. Peraturan Menteri Pendidikan dan Kebedayaan Peraturan Pendidikan Dan Kebudayaan Republik Indonesia Nomor 87 Tahun 2013.

Puspita, M, S Slameto, and ... 2018. "Peningkatkan Hasil Belajar Matematika Siswa Kelas 4 Sd Melalui Model Pembelajaran Problem Based Learning.” Justek| Jurnal Sains \& ....

Sugita, N., A. Ashadi, and M. Masykuri. 2016. "Pengaruh Model Pembelajaran Problem Solving Dan Problem Posing Terhadap Hasil Belajar Ditinjau Dari Kreativitas Siswa Pada Materi Termokimia Kelas XI SMA Negeri 1 Karanganyar Tahun Pelajaran 2015/216." Jurnal Pendidikan Kimia Universitas Sebelas Maret 5(2): 59-67.

Sugiyono. 2016. "Memahami Penelitian Kualitatif." Bandung: Alfabeta.

Syaiful Bahri Djamarah. 2006. "Strategi Belajar Mengajar. Jakarta: PT Rineka Cipta." Syaiful Bahri Djamarah dan Aswan Zain.

Syamsi, Nur. 2012. "Pengaruh Model Pembelajaran Problem Posing Dengan Strategi Search, Solve, Create, Share Terhadap Hasil Belajar Siswa." Penelitian Pendidikan 1(1): 1-7. 